will, in this litigenous age, be generally welcomed.

Part II, by Dr. Brookfield on recent developments in pharmacy and therapeutics, is an important and useful section, giving, as it does, a balanced account of the most important new drugsat a time when the profession is overburdened with literature and samples of new preparations, many of which are of doubtful value or useless.

Part III consists of abstracts with key numbers which should be referred to in conjunction with the major work and the Cumulative Supplement.

As in the past, the editor and contributors are to be congratulated on the excellence of these two new volumes, without which it is impossible to derive the maximum benefit from the beautifully produced second edition of the encyclopaedia.

D.S.L.

\section{CIBA FOUNDATION COLLOQUIA ON ENDROCRINOLOGY, VOL. IO \\ Regulation and Mode of Action of Thyroid Hormone}

Edited by G. E. W. Wolstenholme and Elaine MillaR. Pp. 3 I I, with I I 4 illustrations. London: J. \& A. Churchill. I $957.48 \mathrm{~s}$.

This is the latest volume of the Ciba Colloquia on Endrocrinology, which are now found on the shelves of University departments, research workers and clinicians in all parts of the world. It records the proceedings of a Symposium held at the Ciba Foundation in June, 1956, under the chairmanship of Dr. Pitt-Rivers. Many workers will uby it because they know it will contain a very great deal of indispensable information; the standard of editing and production is as high as in the preceding volumes. There are probably many other people, however, who may be particularly interested in thyroid function, who will find this volume a unique review of present opinion, given by thirtytwo experts from seven countries and enlivened by crisp discussions between them at the end of each of the eighteen papers. Three General Discussions, centring on blood assays for TSH, on analogues of thyroxine, and on future directions in thyroid research, are included. There is, of course, the usual galaxy of references and a very good index.

It is impossible in a brief review to list all the problems discussed at this conference, which range from " Hypothalamus-Pituitary-Thyroid Relationships" (G. W. Harris and J. W. Woods) to "Cellular Actions of Thyroxine and Similar Compounds" (S. B. Barker). It is sufficient to say that anyone engaged in any original work on the thyroid or wishing to deepen his understanding of the gland's function will need to read this book.

\section{UNEXPECTED REACTIONS TO MODERN THERAPEUTICS. ANTIBIOTICS}

By Leo Schindel, M.D. Pp. xii + 146. London: William Heinemann Ltd. I957. I5s.

The content of this book is actually restricted to the toxic effects of antibiotics, apart from a few paragraphs on resistant organisms. It is not sufficiently concise to be part of a refresher course, nor critical enough for the teacher or research workerincluding on one hand numerous case reports culled from the literature, but not, for instance, distinguishing between coincidence and causal relation in the case of Chloramphenicol and blood dyscrasiae. There is, however, a very full bibliography.

Fifteen shillings is a lot to pay for a book of unimaginative format, printed on inferior paper. It might be better if publishers brought out such useful but essentially ephemeral works in paperbacked form.

\section{INTRODUCTION TO ELECTROCARDIOGRAPHY}

By L. Schamroth, M.B., B.Ch., M.R.C.P.E., F.R.F.P.S. Pp. xi +60 , illustrated. Oxford: Blackwell Scientific Publications. 1957. I 2s. 6d.

This is a very simple and concise introduction to the subject, mainly intended for senior students. Numerous sketches help in understanding of the commoner abnormalities and, in accord with current practice in many places, the standard leads are ignored.

\section{EMERGENCIES IN GENERAL PRACTICE}

Specially commissioned articles from the British Medical Fournal. Pp. $\mathrm{x}+470$, illustrated. London: British Medical Association. 1957. 25s.

This book is a collection of the articles specially commissioned for the British Medical Fournal in 1955 and 1956 . The different sections are written by authorities on the subject and are all short and to the point. They include all the commoner medical, surgical and obstetric emergencies, but the list is not exhaustive as conditions such as Addison's disease, myasthenia gravis and snake bite are not described. If one must cavil, and most of the contributions are absolutely up to date, it is a pity that mechanical suction is not mentioned in the treatment of dangerous bronchitis and that veratrum viride is the only hypotensive agent mentioned in the section on eclampsia.

Many doctors will welcome the appearance of this excellent series as a book. 